\title{
Intangible and Indirect Costs of Adaptation to Climate Variability Among Maize Farmers: Chirumanzu District, Zimbabwe
}

\author{
Dumisani Shoko Kori, Joseph Francis, and Jethro Zuwarimwe
}

\section{Contents}

Introduction: Adaptation, an Overview ......................................... 3

The Cost Associated with Adaptation to Climate Variability .......................... 3

Location and Climate of Chirumanzu Resettlement Areas and Rationale for Selection ....... 5

Characteristics of A1 Maize Farmers in Chirumanzu Resettlement Areas ................... 7

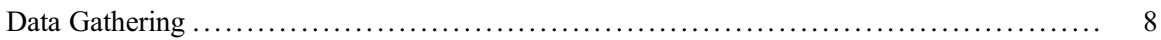

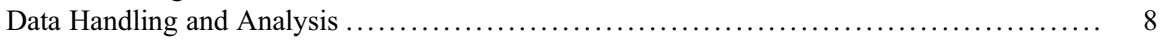

Adaptation Measures Adopted by Maize Farmers in Resettlement Areas of Chirumanzu .... . 9

Changing Planting Dates ................................................. 10

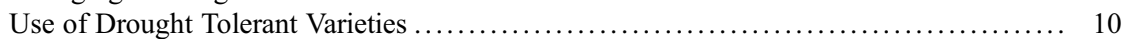

Good Crop Establishment Practices (No Regret Measures) ....................... 11

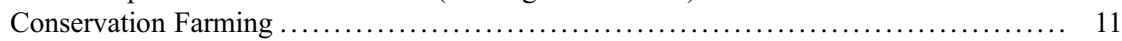

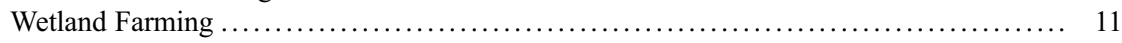

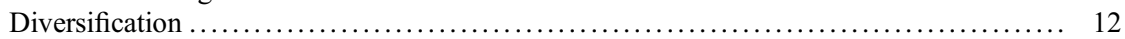

Problems and Dangers Associated with Adaptation Measures Adopted by Maize Farmers ... 12

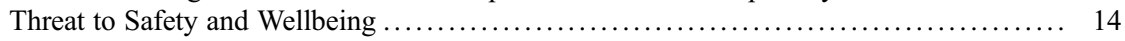

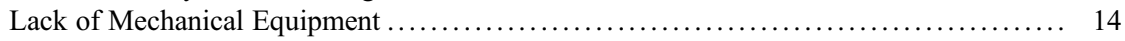

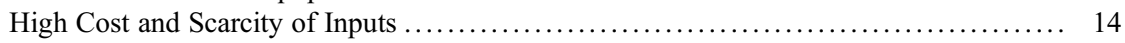

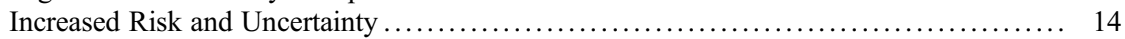

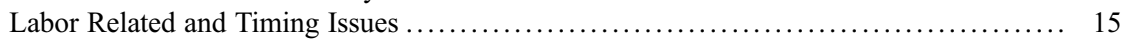

Negative Effects on Productivity and Profits ................................ 15

Intangible Costs Associated with Adaptation to Climate Variability ................... 15

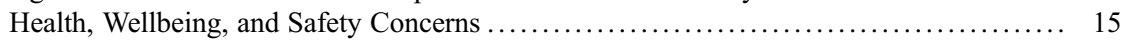

Burden on Household Members .......................................... 17

Worry, Anxiety, and Uncertainty ...................................... 19

This chapter was previously published non-open access with exclusive rights reserved by the Publisher. It has been changed retrospectively to open access under a CC BY 4.0 license and the copyright holder is "The Author(s)". For further details, please see the license information at the end of the chapter.

D. S. Kori $(\bowtie) \cdot$ J. Francis $\cdot$ J. Zuwarimwe

Institute for Rural Development, University of Venda, Thohoyandou, South Africa

e-mail: joseph.francis@univen.ac.za 


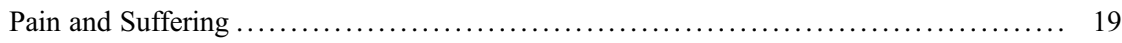

Effort Spent to Facilitate Smooth Implementation of Adaptation Measures ............. 19

Indecision During Allocation of Scarce Resources .............................. 19

Ridicule and Embarrassment Associated with Borrowing Equipment ................ 20

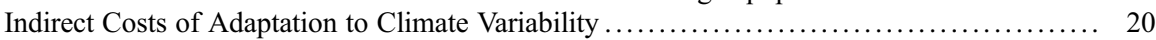

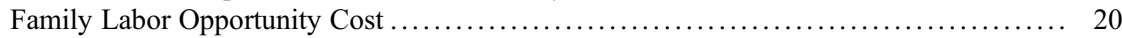

Additional and Unplanned Cost of Production .................................. 21

Yield Losses Related to Risk, Unavoidable Delays, and Timing .................... 21

Huge Investment Cost for Some Adaptation Practices ........................... 22

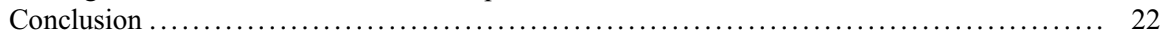

References $\ldots \ldots \ldots \ldots \ldots \ldots \ldots \ldots \ldots \ldots \ldots \ldots \ldots \ldots \ldots \ldots \ldots \ldots \ldots \ldots \ldots \ldots \ldots \ldots \ldots \ldots \ldots \ldots \ldots, 23$

\section{Abstract}

Maize farming in resettlement areas of Chirumanzu District of Zimbabwe is vulnerable to climatic variations. The Government of Zimbabwe encourages maize farmers in resettlement areas to adapt to climate variability through conservation farming and diversification among other measures. It is envisaged that the measures will improve maize farmers' resilience and ability to safeguard food and nutrition security in the country. However, the process of adaptation is dynamic, complex, and multifaceted in nature. Several problems and dangers accompany the process of adaptation. The problems and dangers are associated with intangible and indirect costs. The focus of this chapter is to explore intangible and indirect costs associated with measures adopted by maize farmers in resettlement areas of Chirumanzu in Zimbabwe. Fifty-four maize farmers from four resettlement wards provided the data through semi-structured interviews. Diversification, changing planting dates, use of drought tolerant varieties were some of the measures adopted. Several problems and dangers accompanied the adaptation measures adopted. Intangible costs such as pain and suffering, embarrassment, ridicule, and stereotyping were experienced. Indirect costs including additional and unplanned costs were also encountered. This chapter concludes that intangible and indirect costs associated with adaptation may result in reduced adaptive capacity and resilience of maize farmers. Therefore, national governments should exercise extreme caution and desist from only encouraging farmers to adapt. Rather, they should consider intangible and indirect costs involved while providing solutions to reduce them to avoid situations where farmers are worse off while facilitating sustainable adaptation.

\section{Keywords}

Unintended adaptation effects $\cdot$ Nonmarket adaptation costs $\cdot$ Smallholder farming community $\cdot$ Maize farming $\cdot$ Resettlement areas 


\section{Introduction: Adaptation, an Overview}

Adaptation is an appropriate way to build resilience to climate variability (Biagini et al. 2014; Costinot et al. 2016; Menike and Arachchi 2016) especially under smallholder maize farming. As such, adaptation has been broadly accepted as a policy priority, which explains why it has received extraordinary attention from politicians (Basset and Fogeliman 2013). Following the refusal of some well-developed nations to support the greenhouse gas emission goals of the Kyoto Protocol of 2001, adaptation emerged as the major viable option for furthering the designing of the Climate Change Policy (CCP) (Schipper 2009). The Intergovernmental Panel for Climate Change (IPCC) (2014) states that it recognizes adjustments made even by smallholder farmers in an attempt to reduce vulnerability of farming activities.

Following the agrarian land reforms introduced in 1980 and the Fast Track Land Reform Programme (FTLRP) of 2000 in Zimbabwe, a vulnerable community of farmers emerged in the professed resettlement areas. Since then, the country has been experiencing food insecurity challenges, with almost $50 \%$ of the population being vulnerable to hunger due to the combined effect of unsustainable land reforms and extreme climate variations (Sachikonye 2003). As such, concerns about food and nutrition security have seen the Government of Zimbabwe (GoZ) put more emphasis on adaptation. The Zimbabwe National Climate Change Response Strategy of 2015 acknowledges that farmers in resettlement areas are vulnerable to climatic variations that are currently prevailing in the country. Thus, the GoZ is encouraging maize farmers in resettlement areas to adapt to climate variability so that they can improve resilience and ability to fulfill the massive role of safeguarding food and nutrition security.

Major success stories on adaptation to climate variability have been documented around the globe including the African region and in Zimbabwe. Overall, adaptation has improved maize yields by an average of $15-18 \%$, although effectiveness of measures varies significantly across regions (IPCC 2014). Rurinda et al. (2013) showed that improved timing of planting and adjusting soil nutrient inputs stabilize maize yields under variable rainfall conditions in Zimbabwe. However, it is important to note that adaptation is an investment (Adam and Wiredu 2015) associated with costs as the process introduces new ways of doing things thereby calling for some tradeoffs between new and old ways.

\section{The Cost Associated with Adaptation to Climate Variability}

The process of adaptation is dynamic, complex, and multifaceted in nature. This is because it occurs in biophysical, technical, social, and psychological dimensions that are not static but evolving. Adaptation initiatives are associated with costs (Arfunuzzaman et al. 2016). The IPCC (2014) confirms and highlights that it is costly to adapt to climate variability especially when resources are scarce and capacity is limited which is the case with most of the maize farmers in resettlement areas of Chirumanzu District of Zimbabwe. Literature on climate adaptation, in 
general, does not fully acknowledge intangible and indirect cost of implementing adaptation plans (Milman and Arsano 2014). Yet failure to include the intangible and indirect costs would result in underestimates and misrepresentations of the total cost of adaptation. Adaptation cost literature is still evolving (Fankhauser 2009; Agrawala et al. 2011; Doczi and Ross 2014). It is regarded scant, uncertain, and consensus on overarching cost estimates is lacking (Kumar et al. 2010). There is little peer-reviewed literature on the subject.

Attempts have been made to estimate total adaptation cost. However, adaptation cost estimates only exist at a global level. It is estimated that total adaptation cost ranges from USD9 billion to USD109 billion per year by 2030 (Agrawala et al. 2008; Chambwera et al. 2014). For the agricultural sector, adaptation cost estimates are rare. Agrawala et al. (2011) indicated that with the exception of Mccarl (2007) literature on the cost of adaptation in agriculture is lacking. Mccarl (2007) used a top-down approach to estimate the cost of adaptation in the Agriculture, Forestry, and Fisheries sector. It is estimated that adaptation will cost USD14.23 billion per year by 2030. It is clear that methods that have been used to estimate adaptation costs are quantitative giving much attention to attaching a monetary value to tangible and direct costs. Intangible and indirect costs that do not have a market value are rarely considered.

Agrawala et al. (2008) also observed that there are no accepted metrics for assessing the cost of adaptation measures. As such, multiple definitions for adaptation cost exist. Existing definitions commonly refer to the cost associated with adjustments (Fankhauser 1998) and development initiatives (World Bank 2010) required to reestablish farming conditions prevailing before the occurrence of variations in climate while the IPCC (2014) consider the cost associated with planning, preparing for, facilitating, and implementing adaptation measures in farming practices including transaction costs. The definitions illustrate that there is no consensus as to what constitute adaptation cost. There are various aspects being considered by different authors and organizations. Another challenge is that there is no distinction according to type and/or class of adaptation costs. This makes the issue a complex phenomenon.

In this chapter, some components of the above definitions were adapted. Other considerations mentioned by Smith and Ward (1998) and Meyer et al. (2013) while assessing the costs of natural hazards were also infused. As such, in this chapter, intangible adaptation cost refers to problems and dangers that maize farmers encounter while planning, preparing, and implementing adjustments that cushion the impact of climate variability shocks on maize farming. The problems and dangers are not measurable in monetary terms, as they are not traded on the market as Smith and Ward (1998) illustrated. On the other hand, indirect adaptation cost refers to secondary unintended effects that unfold during implementation of adjustments to cushion the effect of climate variability. The secondary unintended effects include interruptions of normal day-to-day operations, extra demand on available resources such as labor and post adaptation effects that may arise. These may be measurable but not necessarily in monetary terms and are secondary effects of adaptation.

Climate justice scholarship on adaptation raises questions of fairness (Adger et al. 2013; Forsyth 2014). To achieve fairness, intangible and indirect costs arising from the implementation of adaptation measures especially among social classes within 
societies should be recognized. This chapter builds on the concept of "fair adaptation" (Adger et al. 2013; Forsyth 2014; Mikulewicz 2017) and draws upon components of distributive and procedural fairness (Graham et al. 2018) to explore intangible and indirect costs arising from the implementation of adaptation measures among farmers in Chirumanzu. Emphasis is on one of the four principles of fair adaptation, "putting the most vulnerable first" in order to ensure equitable outcomes among those at risk (Paavola and Adger 2006). Thus, concern is on redressing existing inequalities and preventing future ones (Graham et al. 2015) through prioritizing vulnerable resettlement farmers in Chirumanzu District of Zimbabwe and other smallholder farmers elsewhere in similar settings.

Of particular interest to this chapter is the fact that existing adaptation costs have been largely direct and tangible (Meyer et al. 2013). Apart from that, adaptation cost literature has concentrated on attaching cost figures (Mundial 2006; United Nations Framework Convention on Climate Change (UNFCCC) 2008; World Bank 2010) to existing direct and tangible costs yet there are other costs difficult to measure in quantitative terms. This implies that literature on adaptation cost to date does not fully enhance understanding of the overall picture of the cost associated with adaptation. This problem makes it difficult for smallholder farmers to make sustainable decisions and adopt and maintain adaptation plans apart from diminishing adaptive capacity and resilience. Yet governments, researchers, and international organizations are increasingly encouraging adaptation among smallholder farmers.

This chapter, therefore, responds to the necessity of understanding the intangible and indirect components of the cost of adaptation to climate variability. Intangible and indirect costs associated with adaptation to climate variability for smallholder maize farmers in resettlement areas of Chirumanzu District of Zimbabwe were explored. To achieve this, problems and dangers associated with adaptation measures arising from implementing adaptation plans are established. Subsequently, intangible and indirect aspects are discovered. Three important questions are answered in this chapter: What adaptation measures did maize farmers in resettlement areas of Chirumanzu commonly adopt? What problems and dangers are associated with adaptation measures commonly adopted? What are the intangible and indirect costs associated with the problems and dangers?

\section{Location and Climate of Chirumanzu Resettlement Areas and Rationale for Selection}

Figure 1 shows the location of Chirumanzu in Zimbabwe and the resettlement areas in the district. The District lies between longitudes $29^{\circ} 50 \mathrm{E}$ and $30^{\circ} 45 \mathrm{E}$ and latitudes $19^{\circ} 30 \mathrm{~S}$ and $20^{\circ} 20 \mathrm{~S}$. Chirumanzu District is located in the Midlands Province of Zimbabwe. At least $90 \%$ of Chirumanzu District lie in Natural Region III while the remainder falls under Natural Region IV (Gwamuri et al. 2012). Natural Region III receive rainfall ranging from 500 to $750 \mathrm{~mm}$, while Natural Region IV receive 400-510 $\mathrm{mm}$ per annum (Musara et al. 2011).

Chirumanzu resettlement area experiences extreme weather events in the form of severe mid-season dry spells and frequent seasonal droughts (Simba and Chayangira 


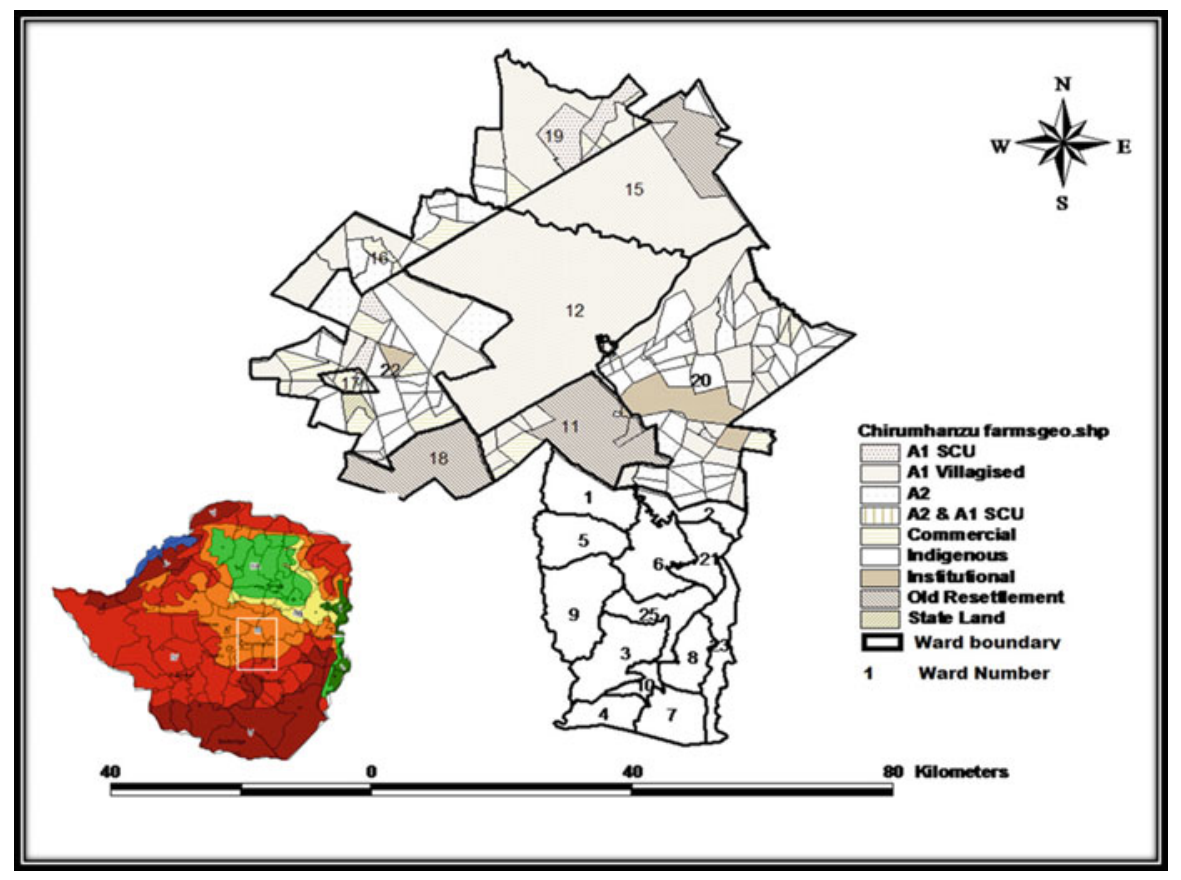

Fig. 1 Map of Chirumanzu District, Zimbabwe showing resettlement areas

2017) yet rain fed agriculture is the major source of livelihood in the area with maize farming being the major farming activity as it is the staple food. Maize farming is largely for consumption. Surplus is often sold providing a source of income for the resettlement farmers. Such a rural setting that is continually battered by climate variations and extreme events presented the need for farmers in the resettlement areas to adapt making them suitable candidates for the study thus presenting a platform for interrogation.

Of the 23 wards in Chirumanzu District, nine (Wards 11, 12, 15, 16, 17, 18, 19, 20 , and 22) are predominantly resettlement areas. These resettlement areas were a result of both the old resettlement program in the 1980s and the Fast Track Land Reform Program (FTLRP) of 2000. Farmers were resettled under A1 and A2 models. This chapter focuses on beneficiaries of the A1 model because these are local communities where the effects of climate variability are largely felt as recognized by the IPCC (2014). Model A1 was designed to address poverty and vulnerability for the landless poor. Furthermore, it was expected that by doing so, the congested communal areas would be depopulated resulting in relatively small farms that could sustain families (UNDP 2002).

Model A1 has three settlement schemes namely villagized, self-contained (Njaya and Mazuru 2014), and old resettlement. In the villagized scheme, each farmer is allocated about one hectare to build homesteads in a village set up. Each resettled farmer got 5-6 hectares away from the village. Grazing area is designated to be 
communal. In contrast to the villagized scheme, self-contained plots ranging from 15 to 30 hectares are allocated per farmer for both cultivation and grazing. Old resettlement scheme is similar to the villagized scheme in its setup. As Thebe (2018) reveals, A1 farms were established on former ranching farms with varying land quality characterized by poor sandy soils to rich black loams. Chirumanzu resettlement areas lie over four main soil types. These are deep sandy, clay, shallow sodic, and sandy loam. These soil types are more or less similar to those found in most smallholder farming communities across Zimbabwe and Southern Africa. Therefore, the information provided in this chapter is of greater applicability to most smallholder farmers.

To explore the intangible and indirect costs of adaptation, four out of the nine resettlement wards were selected. The enquiry was therefore, conducted in Wards 11, 12, 15, and 20. Dominant soil types and resettlement schemes in Chirumanzu District were considered specifically to capture intangible and indirect adaptation cost experiences of different maize farmers operating under different circumstances. There are four dominant soil types in Chirumanzu resettlement areas and three A1 resettlement schemes. Each ward represented a specific soil type and resettlement scheme.

Wards $11,12,15$, and 20 represented sandy loam, shallow sodic, clay, and deep sandy soils, respectively. Apart from this consideration, Ward 11 represented the old resettlement scheme and farmers with relatively more farming experience but with relatively small farm sizes. Ward 12 was selected to represent the villagized scheme and farmers with less farming experience with relatively small farm sizes. Ward 15 was selected to represent self-contained scheme and farmers with less farming experience with relatively larger farm sizes. Ward 20 was unique because it has both the A1 villagized and self-contained resettlement schemes. Furthermore, there is need to note that the imbalance in the main soil types and resettlement models justified inclusion of Ward 20 in the investigation.

\section{Characteristics of A1 Maize Farmers in Chirumanzu Resettlement Areas}

Fifty-four A1 maize farmers were identified from the selected wards so that they could serve as the sources of data through semi-structured interviews. The inclusion and/or exclusion criterion that suited the theme of the investigation was A1 maize farmers who have adapted to climate variability and still had operational adaptation systems in place during the time of the study. Intensive consultation with the District Agricultural Extension Officer and Ward Extension Officers led to the identification of A1 maize farmers who met the inclusion/exclusion criteria.

Out of the 54 farmers, 10 were female. Farmers' age showed skewed outcomes. Forty-three farmers were in the $61-70$ and $71-80$ age groups with only two being 31-40 years old. Farming experience varied from six to more than 30 years. Thirty-one farmers attained secondary education. Only three farmers had tertiary qualifications. Five farmers did not have any formal education but could read and write. Most of the farmers were settled during the period 1998 and 2002 implying that they were settled under the FTLRP. All farmers in Ward 11 were settled in the 
1980s reflecting that they were settled under the old resettlement scheme. Only seven farmers were settled in the 1990s and beyond 2002. Farmers settled under the Fast Track Land Reform were either under villagized or self-contained schemes. Farm sizes for farmers under A1 old resettlement and A1 villagized schemes were either five or six hectares while those in the self-contained scheme were either 15 or 30 hectares. Thirty-five farmers had at least 6 hectares of arable land while more than 50 farmers had between 3 and 10 hectares of arable land under maize production.

\section{Data Gathering}

Semi-structured interviews were conducted with the selected A1 maize farmers. Interviews were conducted in Shona, which is the local vernacular language. This ensured that the respondents had a common understanding of the meaning of the questions compared to the situation had English been used. A semi-structured interview guide with open-ended questions was used to gather data on commonly adopted adaptation measures, associated problems and dangers, as well as the related intangible and indirect costs. Detailed notes of the interviews were taken. Concurrent audio recording of the interview proceedings helped enhance accuracy of farmers' responses.

Data saturation was reached between the 8th and 9th farmer in all the wards. Instead of terminating the interviews, they were continued until the 15th farmer in Wards 11, 12, and 20. This was done in line with the Peterson (2019) advice that seeks to obtain deeper insights. However, in Ward 15 interviews were terminated after interviewing the 9th farmer. An unexpected commotion developed during interviewing, which created hostile conditions that made it impossible to continue with the data collection as originally planned. In total, 54 farmers were interviewed. This final sample was decided on based on the Morse (2016) recommendation that in a grounded theory research such as this one, 30-50 interviews should be conducted. Four additional farmers were included based on the assumption that new and rich data could be generated from them. In addition, Onwuegbuzie and Leech (2007) argue that it is important to ensure that a sample is neither too small to achieve data saturation nor too big to manage.

\section{Data Handling and Analysis}

All audio-recorded interviews were first transcribed verbatim. Textual data from audio recordings and notes taken were stored as a MS Excel spreadsheet on a casebased entry as illustrated by Friese (2016). The file was imported into Atlas.ti Version 8. A grounded theory approach was adopted during the thematic content analysis carried out in Atlas.ti Version 8. Inductive thematic content analysis was performed through reading responses given by the farmers. Textual responses were used to develop preliminary codes through inductive coding. It was performed via open and in vivo coding, in line with the Friese (2016) method. Open coding involved reading the text responses, sentence by sentence while forming detailed 
and structured themes. In this way, a grounded analysis was guaranteed. Simultaneously, codes and resulting code groups that were drawn from primary data were certified while avoiding missing important data. The same approach was used for in vivo coding. In this case, a word or phrase from textual responses was used to represent a code or code group.

Similar or related codes with the same meanings were merged to avoid unnecessary repetition. Irrelevant codes were deleted. Preliminary codes were grouped and merged into code groups. Groups with preliminary codes that were combined yet reflecting two or more concepts were split. Selective coding was used to create qualitative visual representations of the data in the form of network diagrams. Relationships and patterns were created using the resulting codes and groups linking them with quotations to create network diagrams, which were then exported to MS Word for use in presenting results and research report.

\section{Adaptation Measures Adopted by Maize Farmers in Resettlement Areas of Chirumanzu}

Maize farmers in resettlement areas of Chirumanzu adopted six common measures to cushion the impact of climate variability shocks on maize farming. The nature of the adaptation measures suggests that maize farmers in resettlement areas commonly adopt autonomous, ex-post measures (Smit et al. 2000) in response to climate variability shocks and impacts. The act of adaptation is done after farmers have already experienced significant impact costs. This signifies that adaptation is an act of restoration among maize farmers in Chirumanzu rather than intentional. Farmers adopted measures out of desperation in order to restore the losses incurred due to the impact of climate variability. This corresponds to Shoko et al. (2016) who compared adoption rates and preference of adaptation measures among smallholder farmers and found out that for some measures, adoption rates were low while preference was high and vice versa. It was therefore concluded that often farmers adopt adaptation measures not because they prefer them but out of desperation.

It is noticeable that some measures were highly adopted in some wards than in others possibly due to different characteristics of farmers. Of particular importance to this chapter are the soil types and resettlement schemes. Deviant and exceptional cases, adopted by only a few or even one farmer, were also observed among the measures adopted by maize farmers. Furthermore, some measures were adopted for specific stages in the maize value chain, while some were adopted for more than one production stage. Apart from that, some measures were adopted to address several climatic variations.

In some cases, some of the measures adopted were contradictory, while others ended up disadvantaging farmers leaving them in a worse off situation. It is also important to note that out of the six adaptation measures, female farmers adopted five which is a competitive number. This outcome challenges the binary male-female view of gender that women are passive victims of climate change (Nellemann et al. 2011) and confirms that women are proactive agents when it comes to climate 
adaptation (Mitchell et al. 2007; Dankelman 2010). In the following section, the main adaptation measures that maize farmers in resettlement areas of Chirumanzu commonly adopt are described and discussed.

\section{Changing Planting Dates}

Maize farmers in resettlement areas change planting dates in various ways. Farmers either plant early (dry planting), well before the rains start, or late as they are forced to wait for effective rains (sometimes late December or even January). Early and/or dry planting is adopted to address late onset of rains while avoiding delayed planting and falling behind production schedule. Late planting while waiting for effective rains is also normally adopted to address late onset of rains while avoiding poor germination rates and poor crop stand. In some cases, farmers plant their maize crop at different dates of the farming season (staggering). Staggering is adopted to address recurring climate variability shocks and evade total crop failure. Early and late planting are contradictory measures suggesting that adapting to climate variability is not "a one size fits all" approach. Different farmers take different routes depending on background characteristics bringing out farmer heterogeneity.

\section{Use of Drought Tolerant Varieties}

The use of drought tolerant varieties is one of the highly adopted measures in resettlement areas of Chirumanzu. Drought tolerant varieties increases yield in most drought stricken areas by an average of $600 \mathrm{kgs}$ per hectare (Lunduka et al. 2019). Drought tolerant varieties endure moisture stress for a period of six weeks and have high tolerance to dry spells especially during the critical stages of development (Cairns et al. 2013). Due to recurring droughts that are experienced almost every three years in resettlement areas of Chirumanzu, farmers use drought tolerant varieties to improve yields. Drought is one of the limiting factors in rain-fed maize farming especially in sub-Saharan Africa particularly in Zimbabwe (Lunduka et al. 2019). This explains why the use of drought tolerant varieties is one of the highly adopted measures in resettlement areas of Chirumanzu. Common drought tolerant varieties grown by maize framers in resettlement areas of Chirumanzu are hybrid varieties, SC513 and SC403.

Although at times a considerable proportion of farmers receive drought tolerant varieties from the government, some are always not fortunate enough to get access. As such, despite most of the resettled farmers being resource poor (Mushunje et al. 2003; Chinamatira et al. 2016) and confronted with a variety of challenges in acquiring inputs including hybridized seed, Mkodzongi and Lawrence (2019) opined that resettlement farmers strive to self-finance farming activities. This can be argued to include adaptation investments such as the use of drought tolerant varieties. In that case, the use of drought tolerant varieties is an act of desperation that farmers implemented in order to restore and or prevent the losses from the impact of climate variability. 


\section{Good Crop Establishment Practices (No Regret Measures)}

Good crop establishment practices were mainly "no regret measures." These measures include effective and timeous weeding, timeous application of fertilizers, timeous harvesting, and irrigation. According to Hallegatte (2009), no-regret measures are measures that yield benefits even if climate variability does not occur. Similarly, good crop establishment practices are normal practices conducted during maize farming whether there is climate variability or not. Such measures illustrate manipulative behavior and it is argued that they are a subset of adaptive behavior (Thomsen et al. 2012). Good crop establishment practices such as timeous weeding are an example of measures adopted for specific production stages in the maize value chain. Timeous weeding was adopted solely for weed control stage. On the other hand, irrigation is one of the exceptional cases adopted by only a few farmers in resettlement areas of Chirumanzu.

\section{Conservation Farming}

Conservation farming is mainly practiced through the use of planting basins and mulching in resettlement areas of Chirumanzu. These adaptation measures are mainly adopted to conserve moisture while at the same time reducing moisture stress. Planting basins is the use of shallow pits that allow accumulation of water, facilitating rapid infiltration into the soil (Rusinamhonzi 2015). The use of planting basins is highly debated in literature. In Zimbabwe, it is referred to as "dhiga ufe" translated as the "dig and die" technology (Andersson et al. 2011) due to the high labor requirements associated with the practice. Mulching is the use of crop residue and/or other organic material to maintain a permanent or semi-permanent soil cover with the intention of conserving soil moisture (Nyamangara et al. 2014). Maize farmers in resettlement areas of Chirumanzu often use grass and old leaves since crop residue is not adequate to cover large areas of land. Conservation farming is common in Ward 11 with sandy loam soils that quickly loses soil moisture due to accelerated drying of sandy loam soils.

\section{Wetland Farming}

Maize farmers in Chirumanzu often move from their original farms to the wetland areas due to recurring droughts, mid-season dry spells, unpredictable, and unreliable rains. In these wetlands, they can plant as early as September because the soil has enough moisture to sustain germination. Wetland farming is an irregular measure that is an unusual feature in existing research. The adaptation measure is also a characteristic of certain places that have wetland areas, for example, Ward 20 of Chirumanzu. Maize farmers in Ward 20 relocated to the wetland areas in the same locality as their original farms. This is not fully consistent with the conservative narrative on disaster-induced migration (Gray and Mueller 2012). 
The conservative narrative predicts that climate variability consistently increase long-term population mobility and effects are most visible for long distance moves. However, in Chirumanzu Ward 20, effects are most visible for internal moves. It also important to note that wetland farming is a form of maladaptation. According to the IPCC (2014), maladaptation refers to actions that increases the risk of adverse climate-related outcomes, increases vulnerability to climate variability, or diminishes welfare, now or in the future. The concept of maladaptation as Magnan et al. (2016) puts it focuses on the importance of accounting for potential side effects of adaptation to avoid solutions that are worse than the original problem. Moving to the wetland shifts environmental pressures elsewhere and is thus considered a form of maladaptation (Magnan et al. 2016).

\section{Diversification}

Diversification was practiced to avoid the effects of continual decline in maize yield and total crop failure. It is practiced in three different ways. These are crop, enterprise, and income diversification. Farmers grow multiple crops such as small grains, groundnuts that are more resilient to extreme climate variability than maize. Farmers venture into new enterprises like broiler production and look for alternative activities such as gold panning as alternative sources of income than relying on maize alone. Diversification is adopted by farmers with larger farms mostly in the self-contained scheme with more than 15 hectares of land. This illustrate findings by Amare et al. (2018) who projected that farm size has a significant and positive effect on the adoption of diversification to combat climate change impacts.

\section{Problems and Dangers Associated with Adaptation Measures Adopted by Maize Farmers}

Maize farmers in resettlement areas of Chirumanzu experienced several problems and dangers while implementing adaptation measures. Figure 2 shows an imported network diagram depicting a visual representation of the problems and dangers associated with adaptation measures adopted by maize farmers. The network diagram displays code groups (key problems and dangers) and codes (associated problems and dangers). Seven code groups and 32 codes were comprehended. This implies that 32 problems and dangers were identified.

Code groups are presented in red boxes on the network diagram and associated codes in white boxes. Associated codes are linked to code groups with arrows showing how they are related to respective code groups. 


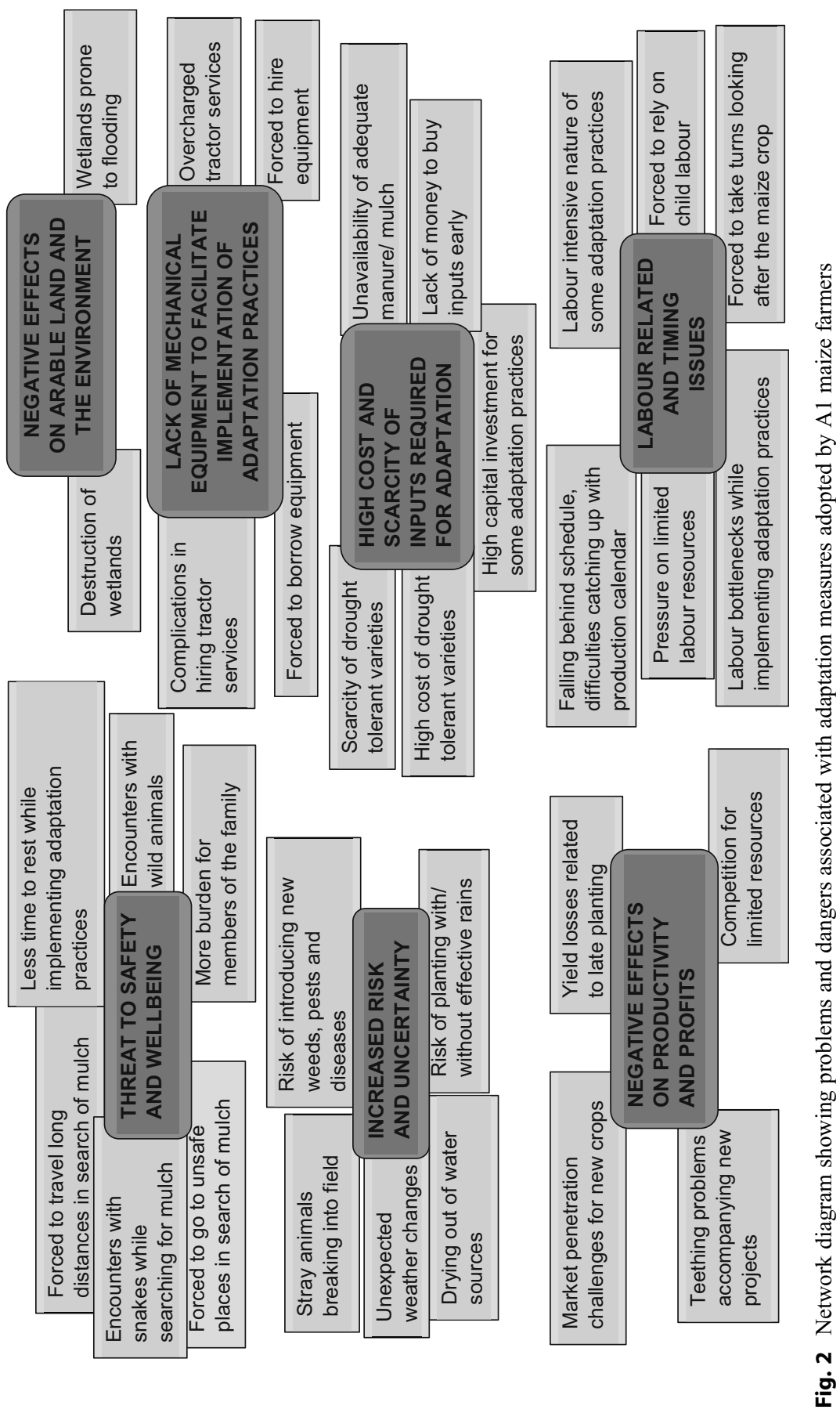




\section{Threat to Safety and Wellbeing}

Some of the adaptation measures implemented by maize farmers pose threat to safety and wellbeing of farmers. Tedious and laborious adaptation measures such as conservation farming result in less time to rest. Mulching forces farmers to travel long distances in search of mulch material. Sometimes they were forced to go to unsafe places in search of grass and old leaves which they normally use as mulch material. Encounters with snakes while searching for mulch material are common.

\section{Lack of Mechanical Equipment}

Lack of mechanical equipment that facilitates implementation of adaptation practices is a major problem. Implements such as ploughs, picks, spades, and hand hoes are required to facilitate implementation of adaptation plans. However, due to resource constraints, farmers do not always have these tools at hand when needed. Farmers are forced to either borrow or hire equipment to execute adaptation plans. However, there is no guarantee that when they borrow they will get the implements. On the other hand, the process of hiring equipment is complicated and this leads to delays and interruptions in implementing adaptation activities. Tractor services are scarce in the area and a few who have them overcharged the services.

\section{High Cost and Scarcity of Inputs}

High cost, scarcity, and continual increase in prices of inputs is also a major problem for farmers while adapting to climate variability. Inputs required to implement or maintain some adaptation practices are not readily available. Where these inputs were found, usually on the black market, they are often charged double the normal price. Scarcity and high cost of inputs hinders farmers from implementing adaptation plans on time.

\section{Increased Risk and Uncertainty}

Farmers encounter increased risk and uncertainty while adapting to climate variability. Unexpected weather changes ruin adaptation plans in general. Planting early pose a risk of stray animals breaking into the field since during September when most people in the area start early planting, people will still be sending their cattle away without someone attending to them. Planting without effective rains often leads to poor germination posing the risk of seed rotting and subsequently seed wastage. Irrigation is associated with the risk of drying out of water sources. 


\section{Labor Related and Timing Issues}

Labor related and timing issues is another key problem that farmers encounter during adaptation. Waiting for effective rains results in delayed land preparation subsequently leading to delayed planting. Resultantly, farmers fall behind schedule. Sometimes they plant late December or January. This puts pressure on labor resources as they try to catch up with production calendar. The effectiveness of their work is compromised as they do things hurriedly. Some adaptation measures are labor intensive. The use of planting basins requires a lot of labor. Such measures burden farmers and they end up relying on children to assist. Furthermore, such measures are limited by labor bottlenecks.

\section{Negative Effects on Productivity and Profits}

Some adaptation measures call for extra production costs. This threatens the sustainability of maize enterprises. Where they practice wetland farming, they plant as early as mid-September. Farmers will need to buy fence to create a barrier in case stray animals might enter into the field and eat maize while they are not watching. Equally, diversification demands extra investment costs to start new project ventures. Farmers ventured into the production of horticultural crops, broiler production, and production of small grains. However, these production activities present a new set of challenges for farmers. Teething problems are experienced as farmers start these new project ventures. Competition for resources is escalated since there is need to balance the resources for all the activities. Farmers who diversify into small grains face marketing strategies as there is no established market for small grains.

\section{Intangible Costs Associated with Adaptation to Climate Variability}

Problems and dangers encountered by maize farmers while adapting to climate variability have several intangible costs. Intangible costs do not have a market value therefore cannot be valued in monetary terms. Tables 1 and 2 summarize adaptation measures adopted by maize farmers, associated problems and dangers, as well as the related intangible costs.

\section{Health, Wellbeing, and Safety Concerns}

Some adaptation measures threaten farmers' wellbeing raising health and safety concerns. Due to the lack of mulch material, farmers and household members are forced to travel long distances and go to unsafe places in search of adequate and suitable materials. As such, there is less time to rest and exposure to danger due to the risk of encountering snakes. With wetland farming, farmers are forced to take 
Table 1 Intangible and indirect costs associated with adaptation measures adopted by A1 maize farmers

\begin{tabular}{|c|c|c|c|}
\hline $\begin{array}{l}\text { Adaptation } \\
\text { measure }\end{array}$ & $\begin{array}{l}\text { Problems and dangers } \\
\text { associated with adaptation } \\
\text { measures }\end{array}$ & $\begin{array}{l}\text { Associated } \\
\text { intangible costs }\end{array}$ & $\begin{array}{l}\text { Associated indirect } \\
\text { costs }\end{array}$ \\
\hline \multirow[t]{16}{*}{$\begin{array}{l}\text { Conservation } \\
\text { farming }\end{array}$} & \multirow[t]{2}{*}{ Tedious and labor intensive } & $\begin{array}{l}\text { Reliance on child } \\
\text { labor leading to } \\
\text { violation of } \\
\text { children's rights }\end{array}$ & \multirow[t]{2}{*}{$\begin{array}{l}\text { Family labor } \\
\text { opportunity cost }\end{array}$} \\
\hline & & $\begin{array}{l}\text { Extra burden on } \\
\text { members of the } \\
\text { family }\end{array}$ & \\
\hline & Lack of mechanical equipment & $\begin{array}{l}\text { Setbacks in } \\
\text { implementing }\end{array}$ & Loss due to delays \\
\hline & \multirow[t]{3}{*}{ Forced to borrow equipment } & $\begin{array}{l}\text { Embarrassment } \\
\text { associated with } \\
\text { borrowing }\end{array}$ & - \\
\hline & & $\begin{array}{l}\text { Ridicule and } \\
\text { stereotyping } \\
\text { associated with } \\
\text { borrowing }\end{array}$ & - \\
\hline & & $\begin{array}{l}\text { Availability and } \\
\text { access of equipment } \\
\text { not guaranteed }\end{array}$ & - \\
\hline & \multirow[t]{2}{*}{ Forced to hire equipment } & $\begin{array}{l}\text { Effort put in hiring } \\
\text { equipment }\end{array}$ & $\begin{array}{l}\text { Unplanned, } \\
\text { additional hiring } \\
\text { cost }\end{array}$ \\
\hline & & $\begin{array}{l}\text { Availability of } \\
\text { equipment not } \\
\text { guaranteed }\end{array}$ & - \\
\hline & $\begin{array}{l}\text { Complications in hiring } \\
\text { equipment }\end{array}$ & $\begin{array}{l}\text { Effort put in } \\
\text { negotiating deals }\end{array}$ & $\begin{array}{l}\text { Opportunity cost of } \\
\text { lost time } \\
\text { negotiating }\end{array}$ \\
\hline & $\begin{array}{l}\text { Overcharged services for } \\
\text { equipment }\end{array}$ & - & $\begin{array}{l}\text { Extra, often } \\
\text { unplanned cost }\end{array}$ \\
\hline & Lack of mulch material & $\begin{array}{l}\text { Setbacks in } \\
\text { implementing }\end{array}$ & - \\
\hline & \multirow[t]{2}{*}{ Forced to travel long distances } & Less time to rest & - \\
\hline & & Wellbeing concerns & - \\
\hline & \multirow[t]{2}{*}{ Forced go to unsafe places } & $\begin{array}{l}\text { Encounters with } \\
\text { snakes }\end{array}$ & - \\
\hline & & Safety concerns & - \\
\hline & $\begin{array}{l}\text { Possibility of introducing new } \\
\text { weeds, pests, and diseases with } \\
\text { mulch }\end{array}$ & - & $\begin{array}{l}\text { Yield loss related to } \\
\text { the risk of new } \\
\text { weeds, pests and } \\
\text { diseases }\end{array}$ \\
\hline
\end{tabular}

(continued) 
Table 1 (continued)

\begin{tabular}{l|l|l|l}
\hline $\begin{array}{l}\text { Adaptation } \\
\text { measure }\end{array}$ & $\begin{array}{l}\text { Problems and dangers } \\
\text { associated with adaptation } \\
\text { measures }\end{array}$ & $\begin{array}{l}\text { Associated } \\
\text { intangible costs }\end{array}$ & $\begin{array}{l}\text { Associated indirect } \\
\text { costs }\end{array}$ \\
\hline $\begin{array}{l}\text { Changing } \\
\text { planting dates }\end{array}$ & $\begin{array}{l}\text { Risk of falling behind schedule } \\
\text { and difficulties catching up } \\
\text { while waiting for effective rains }\end{array}$ & $\begin{array}{l}\text { Worry, anxiety and } \\
\text { uncertainty }\end{array}$ & $\begin{array}{l}\text { Yield losses related } \\
\text { to timing }\end{array}$ \\
\cline { 2 - 4 } & Extra burden & $\begin{array}{l}\text { Opportunity cost of } \\
\text { labor }\end{array}$ \\
\cline { 2 - 4 } & $\begin{array}{l}\text { Possibility of replanting } \\
\text { associated with dry planting as } \\
\text { seed fail to germinate due to } \\
\text { insufficient moisture }\end{array}$ & $\begin{array}{l}\text { Pain and suffering } \\
\text { due to poor } \\
\text { germination }\end{array}$ & $\begin{array}{l}\text { Yield losses related } \\
\text { to unexpected } \\
\text { weather changes }\end{array}$ \\
\cline { 2 - 4 } & $\begin{array}{l}\text { Threatened } \\
\text { wastage }\end{array}$ \\
\cline { 2 - 4 } & emotional wellbeing & - \\
\cline { 2 - 4 } & - & $\begin{array}{l}\text { Cost of additional } \\
\text { seed for replanting }\end{array}$ \\
\cline { 2 - 4 } & $\begin{array}{l}\text { Late planting is associated with } \\
\text { yield losses }\end{array}$ & - & $\begin{array}{l}\text { Additional labor } \\
\text { cost for replanting }\end{array}$ \\
\cline { 2 - 4 } & - & $\begin{array}{l}\text { Yield loss related to } \\
\text { late planting }\end{array}$ \\
\hline
\end{tabular}

turns in looking after the maize crop in case stray animals might break into the field and destroy the crops. While looking after the maize crop, they encounter wild animals such as wild pigs and baboons which may attack them.

\section{Burden on Household Members}

Adapting to climate variability exert excessive burden on household members. Conservation farming, for example, is generally labor intensive, tedious, and time consuming. Farmers usually rely on family members particularly children and women to provide the required labor as they cannot afford to hire or contract workers.

As a result, children get to school late, often miss school, and have little time to play as they are expected to help with implementing adaptation activities. The female folk are excessively burdened as farmers implement adaptation activities. Women are forced to disregard other activities such as going to church. Other important activities like tending to the cattle and goats are left to the children.

Looking after and taking care of the home is put on hold or sometimes neglected. Women face difficulties in coping and balancing household and adaptation chores. Household members struggle with abnormal day schedules and unusual working hours as they sometimes spent the whole day in the field and sometimes wake up as early as 3 o'clock in the morning. Priority is given to adaptation activities more than other household activities. This shows that adaptation activities disproportionately 
Table 2 Intangible and indirect costs associated with adaptation measures adopted by A1 maize farmers

\begin{tabular}{|c|c|c|c|}
\hline $\begin{array}{l}\text { Adaptation } \\
\text { measure }\end{array}$ & $\begin{array}{l}\text { Problems and dangers } \\
\text { associated with adaptation } \\
\text { measures }\end{array}$ & $\begin{array}{l}\text { Associated intangible } \\
\text { costs }\end{array}$ & $\begin{array}{l}\text { Associated } \\
\text { indirect costs }\end{array}$ \\
\hline \multirow{2}{*}{$\begin{array}{l}\text { Use of drought } \\
\text { tolerant } \\
\text { varieties }\end{array}$} & $\begin{array}{l}\text { High cost of drought tolerant } \\
\text { varieties }\end{array}$ & $\begin{array}{l}\text { Effort spent looking for } \\
\text { better priced DTVs }\end{array}$ & \multirow[t]{2}{*}{$\begin{array}{l}\text { Opportunity } \\
\text { cost of time }\end{array}$} \\
\hline & $\begin{array}{l}\text { Scarcity of drought tolerant } \\
\text { varieties }\end{array}$ & $\begin{array}{l}\text { Effort spent looking for } \\
\text { DTVs }\end{array}$ & \\
\hline \multirow[t]{4}{*}{$\begin{array}{l}\text { Good crop } \\
\text { establishment } \\
\text { practices }\end{array}$} & $\begin{array}{l}\text { Tedious nature of practices } \\
\text { such as effective weeding }\end{array}$ & - & $\begin{array}{l}\text { Investment } \\
\text { cost for } \\
\text { efficient } \\
\text { system }\end{array}$ \\
\hline & Time consuming & - & - \\
\hline & $\begin{array}{l}\text { High startup costs associated } \\
\text { with irrigation }\end{array}$ & - & $\begin{array}{l}\text { Investment } \\
\text { cost for } \\
\text { irrigation } \\
\text { system }\end{array}$ \\
\hline & $\begin{array}{l}\text { Risk of drying up of water } \\
\text { sources }\end{array}$ & $\begin{array}{l}\text { Uncertainty and worry } \\
\text { over water source }\end{array}$ & \\
\hline \multirow[t]{4}{*}{ Diversification } & $\begin{array}{l}\text { Capital investment for new } \\
\text { project }\end{array}$ & - & $\begin{array}{l}\text { Investment } \\
\text { cost for new } \\
\text { project }\end{array}$ \\
\hline & $\begin{array}{l}\text { Teething problems while } \\
\text { starting a new project }\end{array}$ & $\begin{array}{l}\text { Pain and suffering as } \\
\text { project fail to take up }\end{array}$ & $\begin{array}{l}\text { Losses due to } \\
\text { failure of new } \\
\text { project }\end{array}$ \\
\hline & Competition for resources & $\begin{array}{l}\text { Indecision/difficulties } \\
\text { allocating resources }\end{array}$ & - \\
\hline & $\begin{array}{l}\text { Market penetration challenges } \\
\text { for new products }\end{array}$ & $\begin{array}{l}\text { Difficulties penetrating } \\
\text { the market }\end{array}$ & - \\
\hline \multirow[t]{3}{*}{$\begin{array}{l}\text { Wetland } \\
\text { farming }\end{array}$} & $\begin{array}{l}\text { Risk of stray animals breaking } \\
\text { into field, Need to take turns to } \\
\text { look after maize }\end{array}$ & $\begin{array}{l}\text { Taking turns looking } \\
\text { after maize, forced to } \\
\text { forego other activities }\end{array}$ & $\begin{array}{l}\text { Opportunity } \\
\text { cost of } \\
\text { activities } \\
\text { foregone }\end{array}$ \\
\hline & Encounters with wild animals & $\begin{array}{l}\text { Possibility of attacks } \\
\text { from wild animals, threat } \\
\text { to safety }\end{array}$ & - \\
\hline & $\begin{array}{l}\text { Wetlands prone to flooding and } \\
\text { waterlogging }\end{array}$ & $\begin{array}{l}\text { Difficulties accessing } \\
\text { wetlands }\end{array}$ & - \\
\hline
\end{tabular}

burden the vulnerable (Barnett and O'Neill 2010) particularly women and children. Reliance on family labor increases vulnerability of women and children. Adaptation in resettlement areas of Chirumanzu is therefore not socially equitable for women and children (Barnett and O'Neill 2010). 


\section{Worry, Anxiety, and Uncertainty}

Farmers fall behind schedule when they change planting dates to wait for effective rains. Farmers worry and feel anxious as they wait with uncertainty for rains to come. Farmers feel helpless as they wait with uncertainty as to when the effective rains will come. Farmers who irrigate also worry over the risk of drying out of water sources.

\section{Pain and Suffering}

Farmers experience pain and suffering due to the poor germination rates and poor crop stand due to insufficient moisture associated with changing planting dates through early and/or dry planting. They are distressed over the inputs, resources, and effort wasted. After early and/or dry planting sometimes very little rains come and they result in seed rot thereby wasting seed, fertilizers, and labor. Farmers also experience pain and suffering as new project ventures fail to start up progressively when they diversify.

\section{Effort Spent to Facilitate Smooth Implementation of Adaptation Measures}

The high cost and scarcity of drought tolerant varieties force farmers to spend a lot of time going from one place to the next, sometimes from one town to the next looking for better priced seed. Drought tolerant varieties are no longer readily available on the market in Zimbabwe. Since 2009, the traditional suppliers of drought tolerant varieties have been failing to meet demand because they were unable to cope with hyperinflation (Dekker and Kinsey 2011). Since then drought tolerant varieties have been scarce on the formal market only covering less than $50 \%$ of the demand (Willems 2014). This facilitated the mushrooming of a parallel market for drought tolerant varieties where they are charged double or more. Incidentally, this forces farmers to make effort looking for better prices drought tolerant varieties they can afford.

\section{Indecision During Allocation of Scarce Resources}

Farmers experience difficulties in allocating scarce resources as they diversify into new project ventures. Potential conflicts in labor allocation and capital investment sharing are common to farmers who diversify. Indecision is therefore common while allocating resources as all the projects will be important to them. 


\section{Ridicule and Embarrassment Associated with Borrowing Equipment}

The lack of mechanical equipment forces farmers to borrow. When they borrow the implements, they are subjected to ridicule and experience feelings of embarrassment. This shows that support networks for adaptation practices sparsely exist among maize farmers in Chirumanzu. Instead of offering social support to other farmers while implementing adaptation practices (Townsend et al. 2015), fellow community members ridicule them. Cooperation and solidarity which are important mechanisms determining the extent to which adaptation measures are adopted are nonexistent among maize farmers in resettlement areas.

The above narrative can be drawn back to the way in which the resettlement program was structured. In particular, the A1 model, communities were created overnight and by chance since most of the times farms were allocated by picking out a number from a hat (Chiweshe 2014). This led to the establishment of "stranger neighboring households" (Barr 2004: 1753) who did not know one another and were therefore forced by to settle and interact. As such, different groups of people with competing views, opinions, and interest would create a conducive environment for noncooperation (Chiweshe 2014).

\section{Indirect Costs of Adaptation to Climate Variability}

Indirect costs are secondary unintended effects of adaptation activities. Although measurable, they are not valued directly on the market. They are unintentional and often unplanned effects of adaptation with a time lag. Tables 1 and 2 summarize adaptation measures adopted by maize farmers, associated problems and dangers, as well as the related indirect costs.

\section{Family Labor Opportunity Cost}

The use of family labor to implement adaptation measures raises the issue of family labor opportunity costs. Although family labor opportunity cost has been identified in existing literature, the indirect aspects surrounding it are not well articulated. In existing literature, labor is considered a variable cost that is direct and tangible as is measurable in man-days per hectare. However, despite the existence of several family labor opportunity cost valuation measures, a common unit of measurements that specifies the cost of important activities foregone while providing labor for adaptation plans is nonexistent.

Maize farmers in resettlement areas rely mostly on family labor. In most cases, farm owners, household members including women and children are forced to forego other important activities while providing labor for adaptation plans. All members of the household provide the required labor for adaptation activities. Commonly, the labor hours provided by household members go unnoticed and mostly unpaid. Hence, the net value of time spent in the next best activity would 
have been foregone. Major effects are on children who are excessively burdened as they are obliged to help before they go to school and after school. As such, adaptation disproportionately burdens the most vulnerable (Eriksen and O'Brien 2007) groups of children in resettlement areas which constitute unsustainable adaptation.

Existing literature on family labor does not go further to establish potential conflicts in labor allocation between adaptation through measures such as planting basins and other household duties. Yet, Rusinamhonzi (2015) indicated that there are indeed potential conflicts in labor allocation between adaptation through planting basins and other activities. This tally with findings of this study where adaptation practices were often drawn back by labor bottlenecks. This study illustrate that the use of planting basins disproportionately burdened maize farmers and their families while reducing the incentive to adapt (Barnett and O'Neill 2010). This explains why very few farmers in Chirumanzu adopted it. Potential conflicts in labor allocation among adaptation plans and competing household duties are a form of adaptation cost that is unnoticed.

\section{Additional and Unplanned Cost of Production}

Maize farmers are confronted with additional often unplanned costs while implementing adaptation plans. Adaptation measures that require special equipment result in maize farmers incurring unplanned hiring costs. Farmers are constrained by the lack of necessary implements such as hoes, ploughs, and tractors to execute adaptation plans. Farmers resort to hiring implements at a cost paid either paid in cash or in kind. This increase the cost of production and most farmers cannot afford it. Wetland farming calls for extra production costs since farmers need to buy fence to create a barrier that obstructs stray animals from entering the field and eat the maize while they are not watching. This relates to the contention of Adger et al. (2009) and Morrison and Pickering (2012) that inadequate technology presents additional unplanned costs for farmers while executing adaptation plans. Payments made in kind are not given much thought; hence, the cost associated usually goes undetected. Early and/or dry planting often results in replanting twice or thrice when seed fail to germinate due to climate variability extremes such as little rains. This generates additional seed, fertilizer, and chemical requirements per hectare thus raising total input cost. These costs are usually misconstrued as normal variable costs without considering the indirect, additional, and unplanned costs associated.

\section{Yield Losses Related to Risk, Unavoidable Delays, and Timing}

Some adaptation measures increased the likelihood of loses rather than gains (Pittelkow et al. 2014). For example, late planting results in grain yield loses of up to $5 \%$ for each week of delayed planting (Nyagumbo 2008). In Zimbabwe, Nyakudya and Stoosnijder (2015) mentioned incidences of pests and diseases as 
the other reasons why late planting often give lower yields. Similarly, this study established that farmers who diversified with small grains ended up failing to get a market for this alternative crop. Nonetheless, since literature on adaptation largely focuses on benefits brought forth by adaptation and neglects the costs, these processes are rarely deliberated in adaptation cost assessments.

\section{Huge Investment Cost for Some Adaptation Practices}

Diversification demands huge investment costs to start new enterprises. Equally, irrigation requires high start-up costs to secure the water source pump and other irrigation facilities for an efficient system. Maize farmers are resource constrained as such these costs are enormous for them.

\section{Conclusion}

Investing in measures that reduce the impact of climatic variation in maize farming is indeed the missing link for A1 farmers in resettlement areas of Chirumanzu. Measures such as conservation farming, use of drought tolerant varieties, changing planting dates, practicing good crop establishment, wetland farming, and diversification may strengthen maize farmers to fulfill their massive role of safeguarding food and nutrition security. The Government of Zimbabwe intends to make adaptation a national priority. On the international front, adaptation has been identified as the only solution for furthering the Climate Change Policy. This has seen an extensive adoption of various adaptation measures around the globe particularly among smallholder farmers including A1 farmers in Zimbabwe. Several success stories on adaptation have been widely documented. Despite considerable variations in effectiveness of adaptation measures in maize farming, yields have been reportedly improved. Overall, adaptation reduces vulnerability and improves resilience while at the same time reducing incidences of rural poverty. However, overall adaptive capacity and resilience among smallholder farmers especially in the African region including Zimbabwe is reportedly still low. This is partly due to the problems and dangers that accompany the process of adaptation. As such, caution must be taken especially in communities that are making efforts to adapt so that the problems and dangers are managed accordingly. The problems and dangers originate from planning, executing, monitoring, and maintenance of adaptation systems. The problems and dangers are associated with some intangible costs that are difficult to measure in quantitative terms and therefore challenging to assign a monetary value which makes them repeatedly ignored in adaptation cost assessments. The problems and dangers are also associated with indirect costs that are secondary effects of adaptation and cannot be easily comprehended at face value as they are not directly measured in monetary terms. This chapter brings to light the fact that in some cases, adaptation results in problems and dangers that limit adaptive capacity and increase vulnerability to some extent. This chapter contributes to existing literature and 
argues that adaptation does not only bring positive outcomes. The chapter progresses the argument that intangible and indirect costs are an enormous part in adaptation planning and cost assessments. This chapter advocates for prioritization of the intangible and indirect costs associated with the problems, dangers, and unintended adaptation effects of adaptation to increase uptake and enhance sustainability. Stakeholders in the climate adaptation arena should not overlook intangible and indirect costs associated to the problems, dangers, and unintended effects that come with adaptation activities in order to enhance social and environmental justice. It is time to practice what is being preached in the climate adaptation arena and not neglect crucial prerequisites of adaptation such as the "first do no harm principle."

\section{References}

Adam B, Wiredu AN (2015) Cost benefit analysis of climate change adaptation measures on soil and water conservation in Northern Ghana (eds: Ministry of Food and Agriculture GUOH, Institute of Farm Management (Germany)). Csir-Savanna Agricultural Research Institute, Ghana. Online, Ministry of Food and Agriculture, Republic of Ghana

Adger WN, Dessai S, Goulden M, Hulme M, Lorenzoni I, Nelson DR, Naess LO, Wolf J, Wreford A (2009) Are there social limits to adaptation to climate change? Clim Chang 93:335-354

Adger W, Tara Q, Lorenzoni I, Murphy C, Sweeney J (2013) Changing social contracts in climatechange adaptation. Nat Clim Chang 3:330-333

Agrawala S, Crick F, Jette-Nantel S, Tepes A (2008) Empirical estimates of adaptation costs and benefits: a critical assessment. In: Agrawala S, Fankhauser S (eds) Economic aspects of adaptation to climate change: costs, benefits and policy instruments. OECD, Paris

Agrawala S, Bosello F, Carraro C, de Cian E, Lanzi E (2011) Adapting to climate change: costs, benefits and modelling approaches. Int Rev Environ Resour Econ 2011(5):245-284

Amare ZY, Ayoade JO, Adelekan IO, Zeleke MT (2018) Barriers to and determinants of the choice of crop management strategies to combat climate change in Dejen District, Nile Basin of Ethiopia. Agric Food Secur 7(37)

Andersson J, Giller K, Mafongoya P, Mapfumo P (2011) Diga udye or diga ufe? (Dig-and-eat or dig-and-die?) Is conservation farming contributing to agricultural involution in Zimbabwe? Proceedings of the Regional Conservation Agriculture Symposium, 8-10 February 2011, Emperor's Palace Hotel and Conference Centre, Johannesburg

Arfunuzzaman MD, Mamnun N, Islam S, Dilshad T, Syed A (2016) Evaluation of adaptation practices in the agricultural sector of Bangladesh: an ecosystem based assessment. Climate 4:11

Barnett J, O’Neill S (2010) Maladaptation. Glob Environ Change Hum Policy Dimens 20:211-213

Barr A (2004) Forging effective new communities: the evolution of civil society in Zimbabwean resettlement villages. World Dev 32(10):1753-1766

Basset TJ, Fogeliman C (2013) Deja vu or something new? The adaptation concept in climate change literature. Geoforum 48(2013):42-53

Biagini B, Bierbaum R, Stults M, Dobardzic S, McNeely SM (2014) A typology of adaptation actions: a global look at climate adaptation actions financed through the Global Environmental Facility. Glob Environ Chang 25(2014):97-108

Cairns JE, Crossa J, Zaidi PH, Grudloyma P, Sanchez C, Araus JL, Thaitad S, Makumbi D, Magorokosho C, Bänziger M, Menkir A (2013) Identification of drought, heat, and combined drought and heat tolerant donors in maize. Crop Sci 53(4):1335-1346 
Chambwera MA, Heal G, Dubeux C, Hallegatte S, Leclerc L, Markandya A, Neumann J (2014) Economics of adaptation. In: Climate change 2014: impacts, adaptation, and vulnerability. Part A: Global and sectoral aspects. Contribution of Working Group II to the Fifth Assessment Report of the Intergovernmental Panel on Climate Change. Cambridge University Press, Cambridge, UK/New York

Chinamatira L, Mtetwa S, Nyamadzawo G (2016) Causes of wildland fires, associated socio-economic impacts and challenges with policing, in Chakari resettlement area, Kadoma, Zimbabwe. Fire Sci Rev 5(1):1

Chiweshe MK (2014) Understanding social and solidarity economy in emergent communities: lessons from post-fast track land reform farms in Mazowe, Zimbabwe. UNRISD Occasional Paper: Potential and Limits of Social and Solidarity Economy, No 1. United Nations Research Institute for Social Development (UNRISD), Geneva

Costinot A, Donaldson D, Smith C (2016) Evolving comparative advantage and the impact of climate change in agricultural markets: evidence from 1.7 million fields around the world. J Polit Econ 124(1):205-248

Dankelman I (2010) Gender and climate change: an introduction. Routledge, United Kingdom

Dekker M, Kinsey B (2011) Coping with Zimbabwe's economic crisis: small-scale farmers and livelihoods under stress. African Studies Centre, Working Paper 93/2011, Leiden

Doczi J, Ross I (2014) The economics of climate change adaptation in Africa's water sector. A review and way forward. Overseas Development Institute Report Working paper. Overseas Development Institute, London

Eriksen SH, O'Brien K (2007) Vulnerability, poverty and the need for sustainable adaptation measures. Clim Pol 7(2007):337-352

Fankhauser S (1998) The cost of adapting to climate change. Working paper no 16. Global Environmental Facility, Washington, DC

Fankhauser S (2009) The costs of adaptation to climate change. Centre for Climate Change Economics and Policy. Paper no 8/Working paper no 7. Grantham Research Institute on Climate Change and the Environment, London

Forsyth T (2014) Climate justice is not just ice. Geoforum 54:230-232

Friese S (2016) CAQDAS and grounded theory analysis. Max Planck Institute for the Study of Religious and Ethnic Diversity, Göttingen

Graham S, Barnett J, Fincher R, Mortreux C, Hurlimann A (2015) Towards fair local outcomes in adaptation to sea-level rise. Climatic Change 130(3):411-424

Graham S, Barnett J, Moertreux C, Hurlimann A, Fincher R (2018) Local values and fairness in climate change adaptation: insights from rural Austrailian communities. World Dev 108 (2018):332-343

Gray CL, Mueller V (2012) Natural disasters and population mobility in Bangladesh. Proc Natl Acad Sci 109(16):6000-6005

Gwamuri J, Mvumi B, Maguranyanga EF, Nyagumbo I (2012) Impact of Jatropha on rural livelihoods case of Mutoko District, Zimbabwe. RAEIN-Africa Secretariat, Windhoek

Hallegatte S (2009) Strategies to adapt to an uncertain climate change. Glob Environ Chang 19 (2009):240-247

Intergovernmental Panel on Climate Change (2014) Climate change 2014: impacts, adaptation and vulnerability. Part A: Global and sectoral aspects. In: Contribution of working group II to the Fifth assessment report of the intergovernmental Panel on Climate Change (eds: Field CB, Barros VR). Cambridge University Press, New York

Kumar K, Shyamsundar P, Nambi AA (2010) The economics of climate change adaptation in India-research and policy challenges ahead. Policy Note 6:10-42

Lunduka RW, Mateva KI, Magorokosho C, Manjeru P (2019) Impact of adoption of droughttolerant maize varieties on total maize production in south Eastern Zimbabwe. Clim Dev 11 (1):35-46 
Magnan AK, Schipper ELF, Burkett M, Bharwani S, Burton I, Eriksen S, Gemenne F, Schaar J, Ziervogel G (2016) Addressing the risk of maladaptation to climate change. Wiley Interdiscip Rev Clim Chang 7(5):646-665

Mccarl BA (2007) Adaptation options for agriculture, forestry and fisheries. A Report to the UNFCCC Secretariat Financial and Technical Support Division. http://agecon2.tamu.edu/ people/faculty/mccarl-bruce/papers

Menike L, Arachchi K (2016) Adaptation to climate change by smallholder farmers in rural communities: evidence from Sri Lanka. Proc Food Sci 6:288-292

Meyer V, Becker N, Markantonis V, Schwarze R, Van Den Bergh J, Bouwer L, Bubeck P, Ciavola P, Genovese E, Green CH (2013) Assessing the costs of natural hazards-state of the art and knowledge gaps. Nat Hazards Earth Syst Sci 13(5):1351-1373

Mikulewicz M (2017) Politicizing vulnerability and adaptation: on the need to democratize local responses to climate impacts in developing countries. Clim Dev 10(1):18-34

Milman A, Arsano Y (2014) Climate adaptation: contradictions for human security in Gambella, Ethiopia. Glob Environ Chang 29(2014):349-359

Mitchell T, Tanner T, Lussier K (2007) 'We know what we need': South Asian women speak out on climate change adaptation, ActionAid and Institute of Development Studies (IDS), University of Sussex

Mkodzongi G, Lawrence P (2019) The fast-track land reform and agrarian change in Zimbabwe. Rev Afr Polit Econ 46(159):1-13

Morrison C, Pickering C (2012) Limits to climate change adaptation: case study of the Australian Alps. Geogr Res 51(1):11-25

Morse JM (2016) Mixed method design: Principles and procedures (Volume. 4). Routledge

Mundial B (2006) Investment framework for clean energy and development. J Sports Sci, World Bank, Washington, DC

Musara JP, Zivenge E, Chagwiza G, Chimvuramahwe J, Dube P (2011) Determinants of smallholder cotton contract farming participation in a recovering economy: empirical results from Patchway district, Zimbabwe. J Sustain Dev Afr 13(4):1-3

Mushunje A, Belete A, Fraser GC (2003) Technical efficiency of resettlement farmers of Zimbabwe. Proceedings of the 41st Annual Conference of the Agricultural Economic Association of South Africa (AEASA), 2-3 October 2003, Pretoria

Nellemann C, Verma R, Hislop L (2011) Women at the frontline of climate change: gender risks and hopes. A rapid response assessment. United Nations Environment Programme, GRID-Arendal. UNEP, Arendal

Njaya T, Mazuru N (2014) Emerging new farming practices and their impact on the management of woodlots in A1 resettlement areas of Mashonaland Central Province in Zimbabwe. Asian Dev Policy Rev 2(1):1-19

Nyagumbo I (2008) A review of experiences and developments towards Conservation Agriculture (CA) and related systems in Zimbabwe. In: Goddard T, Zoebisch MA, Gan YT, Ellis W, Watson A, Sombatpanit S (eds) No-till farming systems. World Association of Soil and Water Conservation, Bangkok

Nyakudya IW, Stoosnijder L (2015) Conservation tillage of rain fed maize in semi-arid Zimbabwe: a review. Soil Tillage Res 145(2015):184-197

Nyamangara J, Mashingaidze N, Masvaya EN, Nyengerai K, Kunzekweguta M, Tirivavi R, Mazvimavi K (2014) Weed growth and labor demand under hand-hoe based reduced tillage in smallholder farmers' fields in Zimbabwe. Agric Ecosyst Environ 187:146-154

Onwuegbuzie AJ, Leech NL (2007) A call for qualitative power analyses. Qual Quant 41 (1):105-121

Paavola J, Adger WN (2006) Fair adaptation to climate change. Ecol Econ 56(4):594-609

Peterson JS (2019) Presenting a qualitative study: a reviewer's perspective. Gift Child Q 63 (3):147-158 
Pittelkow CM, Liang X, Linquist BA, van Groenigen KJ, Lee J, Lundy ME, van Gestel N, Six J, Venterea RT, van Kessel C (2014) Productivity limits and potentials of the principles of conservation agriculture. Nature 517:365-368

Rurinda J, Mapfumo P, van Wijk MT, Mtambanengwe F, Rufino MC, Chikowo R, Giller KE (2013) Managing soil fertility to adapt to rainfall variability in smallholder cropping systems in Zimbabwe. Field Crop Res 154:211-225

Rusinamhonzi L (2015) Tinkering the periphery: labour burden not crop productivity increased under no-till planting basins on smallholder farms in Murehwa district, Zimbabwe. Field Crop Res 170(2015):66-75

Sachikonye LM (2003) From 'growth with equity' to 'fast-track' reform: Zimbabwe's land question. Rev Afr Polit Econ 30(96):227-240

Schipper ELF (2009) Meeting at the crossroads? Exploring the linkages between climate change and disaster risk reduction. Clim Change Dev 1(1):16-30

Shoko D, Oloo G, Francis J, Kori E (2016) Strategy preference vs adoption: a comparative analysis for Agro-Small and Medium Enterprises' survival in a challenging economic environment. The Dyke: Journal of the Midlands State University (Special Issue):150-169

Simba FM, Chayangira J (2017) Rainfall seasons analysis as a guiding tool to smallholder farmers in the face of climate change in Midlands in Zimbabwe. J Earth Sci Clim Chang 8(3)

Smit B, Burton I, Klein RJ, Wandel J (2000) An anatomy of adaptation to climate change and variability. In: Societal adaptation to climate variability and change. Springer, Dordrecht

Smith K, Ward R (1998) Floods: physical processes and human impacts. Wiley, New Jersey

Thebe V (2018) Youth, agriculture and land reform in Zimbabwe: experiences from a communal area and resettlement scheme in semi-arid Matabeleland, Zimbabwe. Afr Stud 77(3):336-353

Thomsen DC, Smith TF, Keys N (2012) Adaptation or manipulation? Unpacking climate change response strategy. Ecol Soc 17(3)

Townsend I, Awosoga O, Kulig J, Fan H (2015) Social cohesion and resilience across communities that have experienced a disaster. Nat Hazards 76(2015):913-938

United Nations Development Programme (2002) UNDP interim mission report. Harare

United Nations Framework Convention on Climate Change (2008) Investment and financial flows to address climate change: an update. United Nations Framework Convention on Climate Change Report. United Nations, New York

Willems F (2014) Access to inputs in Zimbabwe: changes since the Fast Track Land Reform Programme. Dissertation submitted in partial fulfilment of Masters in Human Geography, Globalisation, Migration and Development at Radbound University

World Bank (2010) Economics of adaptation to climate change: synthesis report. The World Bank Group, Washington, DC

Open Access This chapter is licensed under the terms of the Creative Commons Attribution 4.0 International License (http://creativecommons.org/licenses/by/4.0/), which permits use, sharing, adaptation, distribution and reproduction in any medium or format, as long as you give appropriate credit to the original author(s) and the source, provide a link to the Creative Commons license and indicate if changes were made.

The images or other third party material in this chapter are included in the chapter's Creative Commons license, unless indicated otherwise in a credit line to the material. If material is not included in the chapter's Creative Commons license and your intended use is not permitted by statutory regulation or exceeds the permitted use, you will need to obtain permission directly from the copyright holder.

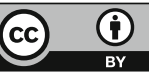

